\title{
Sustainable Tourism Development as a Perspective of Local Development
}

\author{
Karen Garcia Gonzalez*, Carlos Socarras Bertiz and Danny Daniel Lopez Juvinao \\ IPAITUG, University of Guajira, Riohacha, Colombia; kgarciag@uniguajira.edu.co, \\ csocarras@uniguajira.edu.co,dlopezj@uniguajira.edu.co
}

\begin{abstract}
Objective: To analyze sustainable tourism development as a perspective of local development in the department of the Colombian Guajira. Materials and Methods: This research is located within the descriptive studies; this is a field design, non-experimental correlational research. The population consisted of two hundred and twenty-two subjects from the companies "Caja de Compensacion Familiar de la Guajira" (Comfaguajira) and "Luna Guajira". For the collection of information, a questionnaire was designed with 36 items as well as reliability through the AlphaCronbach coefficient, which was 0.97. Findings: Tourism companies in the Department of Guajira formulate their tourism plans; however, they do not generally go through their implementation. Their sustainability is determined by the incorporation of different interests, groups and sectors. It results in bringing as consequences not answering the needs of the tourism sector immediately and at the same time losing the opportunity to take advantage of the tourism potential of the Guajira's department. Results: Global strategies for tourism development were formulated as a perspective of local development in the Department of the Colombian Guajira, with the goal of positioning the Guajira nationally and internationally as the first destination specialized in nature tourism and cultural tourism, with services that meet high quality standards, promote sustainable development and contribute to the improvement of quality of life and decrease of the poverty of its inhabitants.
\end{abstract}

Keywords: Colombia, Local Development, Quality of Life, Sustainable Tourism, The Guajira

\section{Introduction}

From the consolidation of this new global scope, it is considered that the continuous economic, political changes and the arrival of new business dynamics consolidate a panorama with multiple aspects, where the social reality represents an increasingly complex and diverse space, bringing with it a host of challenges for society $\frac{1}{1}$, which leads to mobilize the human being in a creative way with assertive strategies that strengthens psychosocial development that represents an optimal solution for socioeconomic and environmental problems that arise in the face of these global changes.

There may be very few industries that have experienced changes as fast as tourism ${ }^{2}$, in a short time, going on to take second place after the oil sector. At the same time, efforts were made to develop a body of knowledge with the capacity to understand it to guide its planning and development in all areas; the local, regional and international.

Tourism has been growing rapidly in recent years ${ }^{3}$, directly impacting on the socio-cultural development of the villages, where those who export tourism, such as the one who receives it, benefit from it. Thus boosting traditional economic activities and valuing local cultural particularities, while offering employment opportunities ${ }^{4}$.

Tourism is one of the main economic industries at the international level. Being one of the sectors studied the most in social sciences by numerous authors and researchers ${ }^{-}$of work need to be done in the identification of new tourist areas. Tourism has been a growing sector in some departments of Colombia, such as the case of the department of Guajira, a little developed Department, although it has tourist sites that have not been exploited. The Colombian Guajira has an unexploited potential of

*Author for correspondence 
ecotourism possibilities given the biodiversity manifested within its territory ${ }^{6}$.

The Department of the Guajira has few companies, there are no industries to work, that's why tourism is witnessed as the largest source of employment in this Department. Tourism activity has evolved, thanks to this, there are tourism modalities such as ecotourism, ethnotourism, agrotourism, adventure tourism and new forms of tourism management ${ }^{?}$. In view of this panorama, the purpose of this article is to analyze sustainable tourism development as a perspective of local development in the department of the Colombian Guajira.

\section{Materials \& Methods}

This is a descriptive research $\stackrel{8}{ }$, the design is a field ${ }^{9}$, nonexperimental $l^{10}$ cor-relational research ${ }^{11}$. The personnel and executives who work in "Comfaguajira" and the tourist company "Luna Guajira" were selected as subjects, being a finite number of managers and employees in this study. That is why the population census was used, because it is a finite population and easily accessible, in a total of two hundred and twenty-two (222) subjects investigated (Table 1).

The survey is used for data collection ${ }^{8}$, with Likert type response options $s^{12}$. In the calculation of reliability, a pilot test was used on ten (10) subjects and the formula of Cronbach's Alpha was implemented, yielding 0.97, ranking reliability as very high.

In the analysis of the data, the statistical software SPSS 20 was used, supplying the information in frequency distribution of data and generating the explanation according to the average scale of data proposed (Table 2).

Table 1. Population distribution

\begin{tabular}{|c|c|c|c|}
\hline Tourism companies & Managers & Employees & Total \\
\hline Comfa Guajira & 01 & 150 & 151 \\
\hline Luna Guajira & 01 & 70 & 71 \\
\hline Total & $\mathbf{0 2}$ & $\mathbf{2 2 0}$ & $\mathbf{2 2 2}$ \\
\hline
\end{tabular}

Table 2. Scale of interpretation of the average of data

\begin{tabular}{|c|c|c|}
\hline Rank & Alternatives & Categories \\
\hline $1,00 \geq 1,80$ & Totally disagree & Very low \\
\hline $1,81 \geq 2,60$ & In disagreement & Low \\
\hline $2,61 \geq 3,40$ & Neither agree nor disagree & Moderate \\
\hline $3,41 \geq 4,20$ & Agree & High \\
\hline $4,21 \geq 5,00$ & Totally agree & Very high \\
\hline
\end{tabular}

\section{Results and Discussion}

As can be seen in Table 3, in relation to the "Brand Strategy" indicator, $8 \%$ of the surveyed sample believes that this type of strategy is widely used by tourism operators in the Department of the Guajira in Colombia, along with the $51 \%$ that perceive a normal use of these strategies, $28 \%$ consider that it is used moderately, while $12 \%$ consider that they are rarely used and $1 \%$ think that they are almost never used. The calculated mean of the indicator was 3.51, which according to the interpretation scale of the means indicate that these strategies are used with normal frequency.

Regarding the indicator "Promotional Strategy", 18\% of the surveyed sample thinks that this type of strategies is widely used, while $46 \%$ perceived a normal use of these strategies, $15 \%$ considered that it is used fairly, while that $14 \%$ considered that they are used little and 5\% thought that they are almost never used. The calculated average of the indicator was 3.58 , which, like the previous indicator and according to the scale of interpretation of the averages, indicates that these strategies are used with normal frequency.

Contrasting with the theoretical assumptions, we observe that $t^{\frac{13}{3}}$, states that when considering the implementation of sustainable development strategies, it is important to consider it, conceiving it as a participatory process that involves planning, action and execution activities, to realize economic objectives, ecological and social.

While for $\stackrel{14}{ }$, the process of tourism planning is complicated because of those who are responsible for planning and implementing policies, the complexity of tourism, only controls a small part of the variables, without having mastery or full knowledge about the forces, the social actors, the institutions nor the demand.

From the above, it is inferred that the tourism operators in the Department of the Guajira in Colombia, must go from the formulation of the plan to its implementation and its sustainability, determined by the incorporation of different interests, groups and sectors; in addition to giving a comprehensive response to different problems that affect the development of the community in question.

As can be seen in Table 4, in relation to the indicator "Community Tourism", 27\% of the surveyed sample believes that this type of tourism is very present, along with 33\% who perceives it as present, on the other hand $18 \%$ considers that it is fairly present, while $10 \%$ considers 
that it is not very present and $12 \%$ thinks that its use is absent. The calculated average of the indicator was 3.53 , which according to the interpretation scale of the averages, locates the indicator in the "present" category.

Regarding the indicator "Traditional Tourism", 6\% of the surveyed sample thinks that it is very present, together with the $48 \%$ that perceives this type of tourism, $34 \%$ considers that it is present, while $8 \%$ considers that it is not very present and $4 \%$ thinks that its use is absent. In the same trend of the previous indicator, the calculated average of the indicator was 3.45 , which, according to the scale of interpretation of the averages, places the indicator in the "present" category.

Regarding the third indicator "Alternative Tourism", $12 \%$ considers that this type of tourism is very present, on the other hand, $55 \%$ considers it "present", $15 \%$ perceives it as fairly present and while $13 \%$ considers that is present by a small amount, being a $5 \%$ that thinks it is absent. Maintaining the same trend in the calculated average of the indicator, which was 3.57, which according to the scale of interpretation of the averages, places the indicator in the "present" category.

Finally, considering "adventure tourism", the results showed that $22 \%$ considers it "very present", $44 \%$ perceives it as present, while $13 \%$ considers that it is moderately present, with $13 \%$ considering that this type of tourism is not that much present and 9\% considers that it is absent. Following the same trend shown above, the calculated average of the indicator which showed 3.57 that according to the scale of interpretation of the averages, locates the indicator in the "present" category. For Orgaz $\frac{15}{}$, it is necessary to develop different tourist modalities; from alternative tourism commonly as ecotourism.

These modalities collaborate in the development of the nation by incorporating themselves into natural protected areas and national parks that have natural resources, which can be exploited by economically benefiting the people who own the resources, thus committing the inhabitants of the community to be part of the tourist development without affecting the environment. For the Department of the Colombian Guajira this represents an opportunity for regional development to promote tourism using the ecological and environmental resources offered by the area. Hence, it represents a path of local development.

As can be seen in Table 5, in relation to the indicator "Contribution to local development", $23 \%$ of the sample surveyed thinks that it is very present, together with the $39 \%$ that perceives the contribution to local development, however, a $23 \%$ considers that it is moderately present, while $8 \%$ considers that it is not very present and $7 \%$ thinks that it is absent. The calculated average of the indicator was of 3,74 which, according to the scale of interpretation of the averages, locates the indicator in the "present" category.

Regarding the "Development of offers with cultural elements", $29 \%$ of the surveyed sample believes that it is very present, along with the $37 \%$ that perceives present the development of offers, $18 \%$ considers that it is moderately used, while the $7 \%$ considers that it is not very present and $8 \%$ thinks that its use is absent. In the same trend of the previous indicator, the calculated average of the indicator was 3.73, which according to the scale of interpretation of the averages, places the indicator in the "present" category.

At the end of the dimension, the third indicator "protection of historical heritage", the trend is separated from the previous results, $37 \%$ responded as "very present", from which it is inferred that there is a behavior towards the protection of historical heritage, by On the other hand, $24 \%$ considers that it is present, $18 \%$ perceives it as fairly present and $13 \%$ considers that it is not very present, with $8 \%$ saying that it is absent. Maintaining the same trend in the calculated average of the indicator, which showed 3.81 that according to the scale of interpretation of the averages, locates the indicator in the "present" category, in a higher band?

Contrasting with the authors, it is noted that the results match with what was proposed by ${ }^{16}$, for whom local economic development is defined as the process of transformation of the economy and local society, aimed at overcoming both difficulties and existing challenges, that seeks to improve the living conditions of its population through decisive and concerted action among the different local socio-economic agents, both public and private, for the most efficient and sustainable use of existing endogenous resources, through the promotion of local entrepreneurship skills and the creation of an innovative environment in the territory. Using the ecological and environmental resources offered by the area. Hence, it represents a path of local development.

To expose the data collected in Table 6, we started with the first indicator "Economic dimension", 25\% of the sample surveyed believes that it is very present, along with the $29 \%$ who perceives present economic aspects in local development, however, $35 \%$ considers it to be fairly present, while $9 \%$ considers that it is not very present 
and $2 \%$ thinks it is absent. The calculated average of the indicator was 3.66, which according to the scale of interpretation of the averages, places the indicator in the present category.

Continuing with the second indicator, "social dimension", $23 \%$ of the surveyed sample thinks that it is very present, together with the $40 \%$ that perceives this dimension present, $30 \%$ considers that moderately present, while $6 \%$ considers that it is not very present and $2 \%$ thinks it is absent. In the same trend of the previous indicator, the calculated average of the indicator was 3.75, which according to the interpretation scale of the averages, locates the indicator in the present category.

The third indicator referred to the "political dimension", the trend is close to the previous results,
$12 \%$ responded as "very present", on the other hand $41 \%$ considers that it is "present", $25 \%$ perceives it as fairly present and while $6 \%$ considers that it is not very present, with $8 \%$ saying that it is absent. Maintaining the same trend in the calculated average of the indicator, which showed 3.58, this according to the scale of interpretation of the averages, places the indicator in the "present" category.

The arithmetic average of the dimensions showed 3.66 that according to the scale of interpretation of the averages, located to the indicator in the category "present", with which it can be inferred that the different economic, social and political dimensions are present in the company's tourist operators of the Department of the Guajira in Colombia.

Table 3. Sustainable tourism strategies

\begin{tabular}{|c|c|c|c|c|c|c|}
\hline \multicolumn{3}{|c|}{ Indicators } & \multicolumn{2}{|c|}{ Brand Strategy } & \multicolumn{2}{|c|}{ Promotional Strategy } \\
\hline Categories & Score ranges & Scale & A.F & R.F\% & A.F & R.F \% \\
\hline Very used strategy & $4,20-5,00$ & 5 & 17 & 8 & 41 & 18,47 \\
\hline Strategy used normally & $3,40-4,19$ & 4 & 113 & 51 & 103 & 46,40 \\
\hline Medium-sized strategy & $2,60-3,39$ & 3 & 62 & 28 & 34 & 15,32 \\
\hline Little used strategy & $1,80-2,59$ & 2 & 27 & 12 & 32 & 14,41 \\
\hline Strategy almost never used & $1,00-1,79$ & 1 & 3 & 1 & 12 & 5,41 \\
\hline Total answers & & & 222 & 100 & 222 & 100 \\
\hline \multicolumn{3}{|c|}{ Average indicator } & \multicolumn{2}{|c|}{3,51} & \multicolumn{2}{|c|}{3,58} \\
\hline \multicolumn{3}{|c|}{ Average dimension } & \multicolumn{4}{|c|}{3,55} \\
\hline
\end{tabular}

Table 4. Types of tourism

\begin{tabular}{|c|c|c|c|c|c|c|c|c|c|c|}
\hline \multicolumn{3}{|c|}{ Indicators } & \multicolumn{2}{|c|}{ Community } & \multicolumn{2}{|c|}{ Traditional } & \multicolumn{2}{|c|}{ Alternative } & \multicolumn{2}{|c|}{ Of adventure } \\
\hline Categories & Score ranges & Scale & A.F & R.F\% & A.F & R.F\% & A.F & R.F\% & A.F & R.F\% \\
\hline Very Present & $4,20-5,00$ & 5 & 59 & 27 & 14 & 6 & 27 & 12 & 48 & 21 \\
\hline Present & $3,40-4,19$ & 4 & 74 & 33 & 107 & 48 & 122 & 55 & 98 & 44 \\
\hline $\begin{array}{l}\text { Moderately } \\
\text { Present }\end{array}$ & $2,60-3,39$ & 3 & 40 & 18 & 75 & 34 & 34 & 15 & 28 & 13 \\
\hline Little Present & $1,80-2,59$ & 2 & 23 & 10 & 17 & 8 & 29 & 13 & 28 & 13 \\
\hline Absent & $1,00-1,79$ & 1 & 26 & 12 & 9 & 4 & 10 & 5 & 20 & 9 \\
\hline Total & & & 222 & 100 & 222 & 100 & 222 & 100 & 222 & 100 \\
\hline \multicolumn{3}{|c|}{ Average Indicator } & \multicolumn{2}{|c|}{3,53} & \multicolumn{2}{|c|}{3,45} & \multicolumn{2}{|c|}{3,57} & \multicolumn{2}{|c|}{3,57} \\
\hline \multicolumn{3}{|c|}{ Average Dimension } & \multicolumn{8}{|c|}{3,53} \\
\hline
\end{tabular}


Table 5. Socio-cultural behavior

\begin{tabular}{|c|c|c|c|c|c|c|c|c|}
\hline \multicolumn{3}{|c|}{ Indicators } & \multicolumn{2}{|c|}{$\begin{array}{c}\text { Contribution to local } \\
\text { development }\end{array}$} & \multicolumn{2}{|c|}{$\begin{array}{l}\text { Development of offers with } \\
\text { cultural elements }\end{array}$} & \multicolumn{2}{|c|}{$\begin{array}{l}\text { Protection of } \\
\text { cultural heritage }\end{array}$} \\
\hline Categories & Score range & Scale & A.F & R.F\% & A.F & R.F\% & A.F & R.F\% \\
\hline Very Present & $4,20-5,00$ & 5 & 52 & 23 & 65 & 29 & 82 & 37 \\
\hline Present & $3,40-4,19$ & 4 & 86 & 39 & 83 & 37 & 54 & 24 \\
\hline $\begin{array}{l}\text { Moderately } \\
\text { Present }\end{array}$ & $2,60-3,39$ & 3 & 51 & 23 & 41 & 18 & 40 & 18 \\
\hline Little Present & $1,80-2,59$ & 2 & 17 & 8 & 15 & 7 & 29 & 13 \\
\hline Absent & $1,00-1,79$ & 1 & 16 & 7 & 18 & 9 & 17 & 8 \\
\hline Total & & & 222 & 100 & 222 & 100 & 222 & 100 \\
\hline \multicolumn{3}{|c|}{ Average Indicator } & \multicolumn{2}{|c|}{3,64} & \multicolumn{2}{|c|}{3,73} & \multicolumn{2}{|c|}{3,81} \\
\hline \multicolumn{3}{|c|}{ Average Dimension } & \multicolumn{6}{|c|}{3,73} \\
\hline
\end{tabular}

Table 6. Dimensions of local development

\begin{tabular}{|c|c|c|c|c|c|c|c|c|}
\hline \multicolumn{3}{|c|}{ Indicators } & \multicolumn{2}{|c|}{ Economic } & \multicolumn{2}{|c|}{ Social } & \multicolumn{2}{|c|}{ Political } \\
\hline Categories & Score ranges & Scale & A.F & R.F\% & A.F & R.F\% & A.F & R.F\% \\
\hline Very present & $4,20-5,00$ & 5 & 55 & 25 & 50 & 22 & 42 & 19 \\
\hline Present & $3,40-4,19$ & 4 & 65 & 29 & 88 & 40 & 94 & 42 \\
\hline Moderately Present & $2,60-3,39$ & 3 & 77 & 35 & 67 & 30 & 55 & 25 \\
\hline Little Present & $1,80-2,59$ & 2 & 21 & 9 & 13 & 6 & 13 & 6 \\
\hline Absent & $1,00-1,79$ & 1 & 4 & 2 & 4 & 2 & 18 & 8 \\
\hline Total & & & 222 & 100 & 222 & 100 & 222 & 100 \\
\hline \multicolumn{3}{|c|}{ Average Indicator } & \multicolumn{2}{|c|}{3,66} & \multicolumn{2}{|c|}{3,75} & \multicolumn{2}{|c|}{3,58} \\
\hline \multicolumn{3}{|c|}{ Average Dimension } & \multicolumn{6}{|c|}{3,73} \\
\hline
\end{tabular}

According to ${ }^{17}$, the fundamental objective should be oriented towards the greater use of endogenous resources and the diversification of the local productive base through the incorporation of innovations based on the quality and differentiation of products and production processes, as well as the incorporation of management innovations and the necessary social and institutional adaptations. Hence, considering the dimensions for local development becomes a key to success.

\section{Conclusions}

It is concluded that the promotion strategy tends to be the most used in the tour operator companies in the Department of the Guajira in Colombia.However, the brand strategy is also used but at a lower rate.
Likewise, alternative and adventure tourism are the ones that tourism companies in the department of the Guajira in Colombia develop more frequently. Although community and traditional tourism are also developed, the latter is carried out less frequently. It is inferred from the above that the Department of the Guajira is developing tourism alternatives adapting to changes in the tastes of both national and international tourists.

Similarly, socio-cultural behavior in the Department of La Guajira Colombia, is characterized by a high tendency towards the protection of historical heritage, this ensuring that any tourism development plan includes guarantees to preserve the monuments, customs and histories of the region. This coupled with the high behavior in the inclusion of cultural elements in its tourism offer allow us 
to infer the effort that companies in the tourism sector are making for sustainable local development.

Finally, it is concluded according to the registered data that the social dimension is the most impacted in the local development programs.However, the economic aspects impact to a lesser degree, being the political dimension which according to the informants has the least influence in the local development.

\section{References}

1. Delgadillo J. Los terrenos de la politica ambiental en Mexico. Universidad Nacional Autonoma de Mexico: Miguel Angel Porrua; Mexico. 2001. p. 185-211.

2. La cientificacion del turismo. 2005. http://www.eumed.net/ ce/2005/jafari.htm

3. Calle M. Desarrollo local turistico y sostenibilidad. Universidad Tecnica de Machala; Ecuador. 2015.

4. Garcia MF. Estudio de recepcion de audiencias de la campa-a "All You Need is Ecuador". Pontificia Universidad Catolica de Ecuador; Ecuador. 2015. p. 1-124.

5. Orgaz F. El turismo comunitario como herramienta para el desarrollo sostenible de destinos subdesarrollados. Nomadas, Revista Critica de Ciencias Sociales y Juridicas. 2013; 38(2):1-13.

6. Cujía E, Perez S, Maestre D. Ecoturismo, educacion, ciencia y tecnologia, factores de desarrollo sustentable: Caso La Guajira, Colombia. Revista Educacion y Humanismo. 2017; 19(32):174-89.

7. Maldonado C. Pautas metodologicas para el analisis de experiencias de turismo comunitario. Serie Red de Turismo Sostenible Comunitario para Amdrica Latina (REDTURS). SEED: Documento de trabajo num; 2005. p. 1-25.
8. Arias FG. El proyecto de Investigacion, Introduccion a la Metodologia Cientifica. 6ta Edicion. Editorial Episteme C.A; Caracas, Venezuela. 2012.

9. Gomez MM. Introduccion a la metodología de la investigacion cientifica. Editorial Brujas; Cordoba, Argentina. 2006.

10. Hernandez R, Fernandez C, Baptista P. Metodologia de la investigacion. $4^{\text {a }}$ Edicion. Mexico: Editorial McGraw Hill; 2006.

11. Tamayo M. El proceso de la investigacion cientifica. Editorial Limusa; Mexico. 2004.

12. Ruiz C. El Enfoque Multimetodo en la Investigacion Social y Educativa: Una Mirada desde el Paradigma de la Complejidad. Revista de Filosofía y Sociopolitica de la Educación. 2008; 4(8):1-16.

13. Lopez JM, Lopez LM. La capacidad de carga turistica: Revision critica de un instrumento de medida de sostenibilidad. El Periplo Sustentable, núm. 15; Toluca, Mexico. 2008/ p. 123-50.

14. Wilkinson PF. Tourism policy and planning: Case studies from the Commonwealth Caribbean. Cognizant Communication Corporation; New York. 1997 p. 1-250. PMCid: PMC158272.

15. Orgaz F. Turismo y cooperacion al desarrollo: Un analisis de los beneficios del ecoturismo para los destino. El Periplo Sustentable. 2014; 26:47-66.

16. Pike A Rodriguez A, Tomaney J. Local and Regional Development. Routledge; 2006. p. 1-328. https://doi. org/10.4324/9780203003060

17. Arocena J. El desarrollo local: Un desafío contemporaneo, Capitulo IX: Una investigacion de procesos de desarrollo local. Ed. Ediciones Santillana, Universidad Católica de Uruguay; 2001. p. 201-29. 